\title{
The rise and fall of a strategic partnership: Brazilian-Russian relations within the BRICS framework ${ }^{\star}$
}

\author{
V. Jeifets ${ }^{1}$, B. M. Jubran ${ }^{2}$ \\ ${ }^{1}$ St. Petersburg State University, \\ 7-9, Universitetskaya nab., St. Petersburg, 199034, Russian Federation \\ 2 State Department of Planning, Administration and Budget of Rio Grande do Sul, \\ 1501, Avenida Borges de Medeiros, CEP 90020-020, Porto Alegre (RS), Brazil
}

For citation: Jeifets V., Jubran B.M. The rise and fall of a strategic partnership: Brazilian-Russian relations within the BRICS framework. Vestnik of Saint Petersburg University. International Relations, 2020, vol. 13, issue 3, pp. 310-325. https://doi.org/10.21638/spbu06.2020.302

This article analyzes the recent evolution of Brazilian-Russian relations, with an emphasis on their interaction within the BRICS group. The authors claim that beyond the changes and uncertainties in global world order throughout the second decade of the $21^{\text {st }}$ century, the evolution of Brazilian foreign policy, following the internal political conjectures in Brasilia, impacted not only the bilateral relations with Moscow, but also affected qualitatively its participation in the informal grouping. Political turmoil started in the South American nation in 2013 and the eventual impeachment of Dilma Rousseff in 2016 clearly marked a fundamental change in Brazil's global orientation. Brazil abandoned its autonomist and soft revisionist stance on global affairs that characterized the Lula da Silva (2003-2010) and Rousseff (2011-2016) presidencies, and embraced a pro-US perspective, which became even more pronounced after the rise of Jair Bolsonaro in 2019. The article also addresses some prospects on possible paths of cooperation between Brasilia and Moscow in the near future and implications for neighboring countries, especially Argentina and Venezuela (the Venezuelan crisis as a factor of BRICS development is also considered).

Keywords: Russia, Brazil, international relations, BRICS, foreign policy, Argentina.

The informal association of the largest emerging economies, called BRIC (Brazil, Russia, India and China) in 2001, has undergone quite significant evolution over a number of parameters and over time. First of all, the number of its participants increased to five, and the association became known as BRICS since the South African Republic was added to the group. Secondly, the international status and socio-economic situation of group members have sharply transformed, some of them faced serious crisis and the group is not an alliance of emerging economies anymore, the situation became more heterogeneous and complex. The international context has also changed, and the growing redistribution of roles and influence between world centers of power is also very visible. Such dramatical shifts in world economic and political situation affected inevitably the main activities of the BRICS group which tried to respond to the new challenges with the process of its own institutionalization [1, p. 12-14].

* The article was prepared within the framework of the research grant provided by the Russian Foundation for Basic Research (RFFI), Grant no. 19-014-00042 (Latin America in the New World Order: Perspectives and challenges).

(c) Санкт-Петербургский государственный университет, 2020 
Despite numerous skeptical remarks, the BRICS countries managed to show some significant progress since its foundation in 2009. The group established and developed more than 30 areas of cooperation in such areas as economy and finances, health and security, technology, innovation; however, the coordination in some political issues of international agenda is still more complicated problem. Some factors are crucial for promoting the BRICS group (the growing weight of China's and India's economies; the strong strategic alliance between Moscow and Beijing in Euroasiatic region and the abilities of China, Russia and India to find fragile but important balance of forces within the RIC group and the Shanghai Cooperation Organization; the nuclear status of Russia, China and India, as also their common understanding that no one of the BRICS countries is in favour of existing world international order (although they have different perceptions on how this order should be changed).

While the BRICS summits in 2018 and 2019 called for increasing intra-bloc trade, the group is still facing great challenge to improve its economic ties. For example, while China has become Brazil's main trading partner (about $27 \%$ of its exports and $20 \%$ of its imports), India and Russia still maintain low level of trade with this South American nation, and the South Africa's trade with Brazil is even less developed.

The fundamental challenges of BRICS are related on how these countries are committed to expand and strengthen their institutional structure and to increase intra-bloc economic links. It is important to understand to what extent are the countries of the BRICS able and willing to coordinate joint attitudes over the global governance and its reforms, as also over the regional agenda issues and to take into account the demands and necessities of each one in this dialogue.

While the debates over the BRICS abilities to create an alternative to existing global governance institutions (such as G7 and the IMF) are still strong, in Spring of 2019, the BRICS group demonstrated that it is not going to try to destroy the existing rules of game, but is committed to coordinate its own activities with such institutions as World Bank and the Asian Development Bank. The BRICS countries managed to regularize its multilateral consultations converting them into annual Summits of the heads of integrating countries. These summits became the place for discussions over number of global and regional issues in economic and political spheres.

Brazilian-Russian relationship within the BRICS context is the issue of special interest as it not only affects the group as a whole, but also has implications in Moscow's policy in Latin America and in Brazilian strategy towards the main global geopolitical centres. It is worth to mention that the latest version of the Foreign Policy Concept of the Russian Federation (2016) has demonstrated a serious reconfiguration of Moscow" attitudes towards whole the Latin American region: while the references to strategic alliances in Latin America disappeared from the document, Brazil has become one of the important priorities of Russian foreign policy, however, not as a separate country, but as BRICS member. According to the Concept, BRICS is one of the possibilities to "ensure the sustainable manageability of global development, which requires collective leadership from the major States that should be representative in geographic and civilization terms and fully respect the central and coordinating role of the UN" [2]. The BRICS is perceived by Russia as a platform for joint and coordinated activities in some significant issues of international agenda, as a mechanism for economic cooperation and as a mode to expand trade and financial ties with different countries. It is worth to note that the relationship within the 
group is developing not only at the level of the BRICS as whole but also as bilateral and even trilateral basis. Within this framework both Russia and Brazil manage to negotiate issues and topics relevant for them, including the relationship with other regional nations. The South American giant keeps its importance for Moscow not only because of the huge volume of trade (the first trade partner of Russia in whole the hemisphere), but it is still considered as one of the keys to the continent. According to the Concept of participation of the Russian Federation in BRICS, every group member is relevant, among other aspects, because of its role in the regional and sub-regional organizations (in case of Brazil, there is a reference to South American Common market and the Community of Latin American and Caribbean States [3].

\section{Between strategic alliance and cooling relations: the evolution of Russian-Brazilian ties}

Since the collapse of the Soviet Union in 1991, Brazil and Russia have embraced similar approaches concerning economic policy and global integration. While in early 1990s both of them adopted a neoliberal agenda, which combined privatisation with trade liberalisation, in 2000s they strived to pursue a more autonomous path built on promoting regional blocs and gradually forging ties with other emerging centres, without relinquishing the centrality of the connections with North America (in case of Brazil) and Western Europe (in case of both Brazil and Russia). However, at least since 2011 and more clearly after 2015 their political paths have shown a gradual differentiation, thus cooling the strategic partnership which was well cherished along the previous decade [4].

Systemic factors do influence the behaviour of specific actors, although that process shall operate indirectly and distinctly for every player. While it is true that current global, which reflects a given balance of power, puts pressure and constraints on every actor. However, as every player possesses distinct sources of power of power which can be determined both in quantitative and qualitative, the room for manoeuvring shall also vary.

Concretely, we agree that global balance of power has shifted from a clear unipolar trend in early 1990s towards an intricate and diffuse multi-polarization, with the emergence of new powers, such as the case of China and India, the revival of elder others, such as Russia itself, even though the United States still has conserved the leadership particularly in military capabilities and influence in a dense net of alliances, as the case of North Atlantic Treaty Organisation (NATO).

Foreign policy of specific nations is indeed developed under global constraints, but that does not merely imply that individual behaviours are explained by global stimuli. The response of every state will depend also on material capabilities it possesses and also its role in global affairs. For instance, although the United States and Chad are susceptible to be attacked by transnational terrorist groupings, the former has certainly much better means to defend against those threats. Also, the domestic disputes which occur within a given nation are crucial to understand the rationality behind a foreign policy.

When analysing the evolution of Brazilian-Russian relations since the fall of the Soviet Union in 1991 we recognize at least three very distinct phases ${ }^{1}$. The first one, from

${ }^{1}$ Within each of these three moments it is possible to observe interesting subdivisions, explained by contextual dynamics. For instance, in mid 1990s Brazilian diplomats seemed more interested in fostering 
1991 until early 2000s, did not induce their interaction beyond diplomacy. While in early 1990s the prevailing neoliberal bias in Brasilia and Moscow was a limiting factor as they acted as competitors for foreign investment and cut expenses in governmental projects severely damaged any prospect of cooperation, in particular in science and technology [5]. After Russian political reorientation in 1996, the dialogue between both nations eventually restarted, but only for a while: first, the Brazilians were reluctant to broaden relations; second, and more important, both countries suffered serious setbacks that curtailed their ability to act autonomously in global affairs and to make progress in bilateral relations:

Russia underwent a major banking and financial crisis in 1998, which eventually damaged the cabinet of Sergei Kirienko and installed a period of renewed turbulence. In the following year, Fernando Henrique Cardoso's economic team abruptly devaluated Brazilian currency Real to tackle the persisting dollar shortage in the economy. The decision casted a fierce criticism on a government that had been elected under the symbology of low inflation and a strong new currency (Real was introduced in 1994, when Cardoso was Ministry of Economy). Brazilian foreign policy was also under questioning at home at that time due to poor results of an agenda that envisaged free market and more integration with the global economy. Political and economic turmoil in both nations was an additional factor to prevent the progress of bilateral relations: it meant that both nations needed to concentrate efforts in solving priority and urgent questions at home, and to relinquish secondary goals for another time [6].

Around the turn of millennium national strategies were under review in both Moscow and Brasilia. In Russia, nationalist discourses could be clearly heard after 1996 when Evgeny Primakov was designated as the chief of Ministry of Foreign Relations, and the ascension of Vladimir Putin in 2000 marked the consolidation of such stance (although this trend for sovereign foreign policy didn't exclude in Russia continuing approximation with the European Union - this policy was, rather, considered as possibility to split Euroatlantic "solidarity" between Europe and the USA). During Cardoso's second term, Brazilian foreign policy underwent some subtle changes, and Brasilia choose to not support US military involvement in Afghanistan since 2001 and criticized the decision to invade into Iraq in 2002. The presidency of Luis Inacio Lula da Silva (2003-2010) strengthened Brazilian autonomy towards the United States and encouraged the interaction with nations of the global South.

Throughout the 2000s Brasilia and Moscow strived to develop what both coined as 'strategic partnership'. The augmentation of Brazil-Russia relations at that time was possible thanks to the coexistence of some systemic factors: (1) the increasing perception around the world at that time that US-unilateralism could threaten global stability and spark conflicts; (2) improved terms of trade for both nations with the appreciation of exported commodities (energy supplies, minerals, agricultural goods); (3) the rapid ascension of China, providing sound profits for external trade of Brazil and Russia, while also generating new patterns of economic dependence.

As early as 2000, Brazilian and Russian governments established an important diplomatic mechanism of cooperation, the High-Level Commission, which is led by Brazilian vice-president and Russian Prime Minister. Initially, dialogue focused primarily on trade, including occasional unilateral barriers and other litigations. Other themes, such as sci-

political entanglements than their Russian counterparts; some years later the picture inverted. Notwithstanding those nuances, the entire decade can be correctly described as a phase of very limited interaction. 
ence and technology cooperation, political collaboration in international organisations became a hot topic in particular during Lula da Silva's administrations, when Brazil's general foreign policy assumed a more independent path from the United States.

Despite the gradual political convergence of both nations on crucial global problems, including the necessity of restructuring the United Nations Security Council (since 2002 Russia has endorsed a permanent seat for Brazil), and the criticism on rising US militarism, strategic partnership achieved meagre results throughout the 2000s. While trade flux increased manifold during the decade, partially thanks to the thriving national economies and also the trade talks, strategic and military cooperation remained rather limited. In 2008, the Brazilian plan for modernising its air force, known as FX-2, excluded without detailed justification the Russian offer, which sought to provide Sukhoy-30 units and encompassed technology transfer, a long-standing Brazilian demand. Some analysts are convinced that pressure from the US (which was also in the tender along with France and Sweden) might have been decisive for such a move [7]. The case illustrates the limitations imposed by Washington's hemispheric hegemony which hampered the evolvement bilateral relations during the very peak of Brazilian activism in global affairs, a pattern that became much clearer over the following years.

By early 2010s bilateral relations were said to be very potential to become fully strategic. The case for a promising future was well connected with the conjectures in both Brasilia and Moscow. Both nations managed to overcome the 2007-2009 Global Crisis much more quickly than developed nations in West Europe and North America. Furthermore, both governments felt motivated when joining new political mechanisms that could ensure them a higher leverage in international relations. At that time the group of BRICS vowed to challenge the correlation of power in US-dominated international organisations, particularly the International Monetary Fund (IMF), World Bank (WB) and the World Trade Organisation (WTO).

Optimism was even more fashionable within Brazil. Driven by high popularity and sound economic performance, Lula da Silva managed to nominate his successor and party colleague Dilma Rousseff in 2010, prompting expectations that autonomist foreign policy would be maintained or even strengthened.

The rise of Dmitry Medvedev in Russia (2008) and Dilma Rousseff in Brazil (2011) represented a general continuation for nations, although it is possible to note some new nuances in terms of foreign policy. Medvedev pursued a more favourable view to some universal instruments, which eventually led to Russia's accession to WTO. Rousseff, while keeping the regional integration as a key priority and bearing a soft revisionist stance on many multilateral regimes as her predecessor, the country dramatically mitigated its protagonism and assumed a rather reactive behaviour. South-South cooperation and the African vector lost their momentum, although BRICS continued to attract attention from Brazilian diplomats.

Moreover, the new leaders were confronted by new direct challenges in global and regional politics: Medvedev was embedded in a military clash with Georgia in 2008 some months after his inauguration, while Rousseff was a major target in the espionage system conducted by US intelligence agencies, according to a leakage provided by Edward Snowden. Their room for manoeuvring reduced in the same proportion of the rentability of their exports, as international commodities prices started to fall after 2009. 
In case of Brazil, the shrinking international activity can be also seen as a by-product of changing environment in its decision-making process. There is a consensus among analysts that Rousseff did not put foreign policy among her government's priority. The idea of 'presidential diplomacy', initiated during Cardoso and intensified in Lula's administration, was abandoned in favour of a diplomacy conducted by diplomats themselves, while the relative reputation of Itamaraty decayed vis-à-vis other ministries $[8 ; 9]$.

Even though Rousseff's administration was less attentive to global affairs, in the first half of the 2010s many bilateral projects envisaged in previous years started to mature and generate results. The first significant military purchases from Russia started to be provided for the Brazilian Forces still in 2010, as the case of 12 helicopters units of Mil Mi-24 class. The presence of Russian capitals in Brazil also started to be felt at that moment, notably in the hydrocarbons sector. Four major companies have been active in Brazil: NK Rosneft, Lukoil, Gazprom and Neftegazgeodeziya. Rosneft is the most prominent and has a local subsidiary, Rosneft Brazil, which has developed a project of oil extraction in Solimões basin in the state of Amazonas since 2013 [10].

However, cooperation has stalled in many other spheres. Nuclear energy and space technologies have been discussed since the Soviet times, but successive cut expenses and funding shortages, as well as the pressure from third countries have detained or halted the implementation of projects.

Disruptive features became much more visible during the tough economic and political turmoil in mid-2010 in Brazil and also in Russian surroundings. In case of Brazil, political agitation since the 2013 protests and Rousseff's impeachment in 2016 have enormously impacted several aspects of governmental life, including its own foreign policy. Brazilian international activism, which was already retrenching from many global agendas during Rousseff's administrations, has diminished further in Temer's presidency. For two years of Temer's administration, Brazil has been officially visited only by some neighbouring nations heads of state and also by some leaders attending to 2016 Summer Olympic Games, in Rio de Janeiro. Visits of bilateral character have been limited to some neighbouring nations' heads-of-state, while Temer himself has avoided trips abroad. Although the nation is still represented in some forums, including BRICS, G20, its participation has been described as feeble and inconsistent in the media [11].

Factors for extra retrenchment of Brazil in the period can be found in nearly all levels of analysis. Firstly, in material terms, Brazilian economy started in 2014 an acute recession that some commenters refer as depression, due to the persistency and complexity of the crisis. Foreign policy also has been a topic of radicalisation among interest groups: while the traditional protectionist-liberalisation divide still echoes those disputes, embedded relations with China and the relevance of regional integration make the question much more complex. Under the influence of neoliberal ideas, Temer's government, supported by most part of political and economic elite, has cut expenditures that has damaged many projects in Brazil's international affairs. Furthermore, foreign policy remains far from priority for a government that has been struggling with colossal unpopularity.

Almost simultaneously, the armed conflict in Eastern Ukraine has created additional problems for Russian global strategy. However, differently from its South American counterpart, Russia has succeeded in sustaining its autonomist global strategy through renewal of its links with China and projecting its military capabilities in Syrian Civil War. 
Although political and diplomatic dialogue remained quite cordial between Brazil and Russia in a more uncertain international scenario, the same cannot be applied for trade and technology cooperation. The adoption of a revived neoliberal agenda since 2015 by the Brazilian government has severely reduced its ability to invest and to commit with international agreements, including those with Russia. Not surprisingly Michel Temer ended talks on the acquisition of Russian Pantsir missile system in 2017, allegedly due to budget shortfall.

While the imposition of embargo against agricultural imports from Western economies by the Russian government in 2014 has created opportunities for Brazilian producers, trade flow remains quite underdeveloped due to persisting difficulties in Russian economy and also the technical problems verified in Brazilian farms. Another problem less discussed is in operational level: as diplomatic talks have focused on technical barriers, Brazil-Russia trade remains heavily dependent on European and North American exporting trade and insurance companies. It means that any damage on Russia-West relations might force companies to abandon Russian ports and consequently sever links with Brazil.

The election of Jair Bolsonaro in Brazil in late 2018 not only blurred the prognostics for the bilateral relations, but also put in question the very identity of Brazil in international relations. During electoral campaign, he criticized the increasing dependence of economic relations with China, a nation that was simply 'buying' Brazil [12], and promised to realign with the United States [13].

\section{Venezuelan disuniting factor within the BRICS and Russian-Brazilian relations}

The Venezuelan political crisis became the main source of contention between Brazilian and Russian statesmen in decades. During the preparation of BRICS summit in Brasilia in November of 2019 the interminable Venezuelan political and economic turmoil became shadow for whole the cooperation within this group. The systemic socio-economic crisis has as one of its consequences a massive migration from Venezuela to bordering countries affecting negatively the situation in many of them. The political crisis became especially serious as many countries rejected the results of presidential elections considering them fraudulent ones. Just a few days after his inauguration in 2019, Mr. Bolsonaro officially recognized Juan Guaidó as Venezuela’s president and promised to provide support to local opposition against president Nicolás Maduro, following the path traced by the US and some Latin American nations, as Colombia, Peru and Chile [14]. Jair Bolsonaro in 2019 even admitted the possibility of Brazil's participation in armed intervention into the neighbouring country in case of necessity. The remaining BRICS nations maintained the recognition of Mr Maduro as the sole and legitim Venezuelan representative, while Russia also offered material support to loyalist side in the conflict.

Russia and China, as permanent members of the UN Security Council, made it clear that both nations are against any foreign intervention into Venezuela's internal political crisis and that this issue should be resolved by Venezuelan themselves, and they have consistently opposed the introduction of economic and financial sanctions by Washington and its allies. Moscow and Beijing continued to support Maduro's government financially 
and by purchasing Venezuelan oil which was and is one of the crucial factors for Maduro's government surviving.

Bolsonaro's propositions for other BRICS members to convert the fight against terrorism and transnational organized crime was compatible with the priorities of the Shanghai Cooperation Organization. However, this synthony became rather formal as the divergences over the Venezuelan issue were dividing the group in political area (especially since Brazil started its approximation with the US administration). As prominent Argentinean-Venezuelan analyst Andres Serbin pointed out, the situation was somehow fixed as Russia, Brazil, and China supported the idea of Maduro-opposition dialogue in Oslo and Barbados, and as Brazil's military (quite pragmatic and oriented to cooperation with many countries, not only with the US) made its pressure on the government with a purpose to continue in BRICS [15].

The Venezuelan issue didn't disappear from BRICS discussion, and there was a polemic between Brazilian diplomacy head Ernesto Araújo who asked to attend "the voice of liberty" of the Venezuelan people and Russian foreign minister Sergei Lavrov who insisted on the necessity to act within the marks of international law and to abstain from any intervention into domestic affairs of sovereign nations. The final declaration of the meeting of the foreign ministers didn't mention the Venezuelan issue, but that was not the point. The heads of five BRICS members managed to concentrate on other agenda issues demonstrating that they are able to find common language with a purpose to carry on the group priorities. It is also worth to mention that Brazilian government managed to convince some Guaido's supporters to leave the Venezuelan embassy in Brasilia occupied by them during the XI Summit [16]. The resolution of the incident might be considered as the good will expressed by Brazilian authority towards Moscow and Beijing, but also to Brazilian worries about the safety of its own representatives in Caracas. The final remarks on the necessity to find "peaceful, diplomatic regulation" of the Venezuelan issue was still more significant [17]. As an interesting detail, one can note that both Russia and China didn't make drastic declarations over the Bolivian crisis where the President Evo Morales (known as a political partner of Russians and Chinese in some international issues) was ousted from the office during the BRICS summit; and the new government immediately broke relations with Venezuela. This measured reaction was also a sign of Moscow and Beijing to maintain good level of dialogue with Brazil (which had cherished the change of government in neighboring Bolivia).

Nevertheless, Venezuelan crisis had, at least, one serious consequence for BRICS policies. While some previous summits were marked with presence of the heads of states and governments of countries which were not BRICS members, the 2019 summit broke this tradition. Brazilian officials decided to organize the summit without inviting its South American partners, thus breaking with a tendency initiated by Brazil itself in 2014, when it invited all other South American leaders to participate to a joint summit between BRICS and UNASUR (Union of South American Nations). Although Brazilian diplomats strived to justify such a move as a way to bolster 'intra-BRICS' cooperation, analysts agreed that the meeting weakened not only Brazilian leadership in the region, but also contributed to inflict division and eventually impair the group. Due to Brazilian objections, political crises in South America, such as in Bolivia, Chile and Venezuela were not mentioned in the final declaration [18]. 
It should be also noted that the outreach format became something impossible to fulfill as there were two presidents in Venezuela, and BRICS countries took different stands on who was the legitimate head of state in this South American country. As it was impossible to reach an agreement, no other country was invited to Brasilia. There were some unofficial critics of such a decision as the diplomats sent from Moscow, Beijing, New Delhi and Pretoria were interested to be able to meet as much leaders of Latin American countries as it were possible during the summit. However, Bolsonaro maintained his firm stand over the issue [19]. Moreover, Brazil (although unofficially) expressed the lack of will to develop outreach format.

The XI BRICS summit in November 2019, held in Brasilia, marked some significative changes in Brazilian positions in comparison to previous years. As previously mentioned, Brazil broke with the practice of inviting neighbor nations - BRICS outreach. Secondly, political disagreements prevented the bloc to assume a coherent position on the situation in several Latin American crisis, due to Brazil's dissonant voice in the group, although the final declaration managed to call for peaceful solutions in regional conflicts, particularly in the Middle East (Syria, Yemen and Afghanistan) and the Korean Peninsula [20] and the reaffirmation of sovereignty as inviolable principle in international relations. The latter was seen by Brazilians as an implicit group's support for the active quarrel between Brasilia and some European capitals over the inability of Brazilian authorities to overcome the environmental crisis in Amazon. While the Final Declaration contains traditional references to the multilateralism, it also included some mentions of national sovereignty and independence (in their relationship with international and transnational organizations), and there are no doubts that such modifications were the outcome of Brazil's diplomatic efforts.

Bolsonaro and his country demonstrated clearly that Brazil is currently more interested in the BRICS' activity which has to do with economy and innovation, while the political cooperation is not a priority (at least, until the countries-members would be able to find a consensus in such issues).

Consequently, Bolsonaro met Chinese President Xi Jinping and both leaders revealed that the previous declarations about reconsideration of commercial relations are not part of agenda anymore. At the contrary, Brazilian Minister of Economy Paulo Guedes announced that two countries would try to create a free-trade zone. The inauguration of the New Development Bank of BRICS' office in Sao Paulo might be seen as another sign of reconciliation between Brasilia and Beijing. Up to the moment, only 4 projects of the Bank (less than 10 percent) are Brazilian, but the activities of the first NDB office in Latin America should somehow to repair the situation. According to Paulo Nogueira (first Brazilian director of the NDB), the Bank "lacks good management" and the persons and countries who had taken the decision to create the NDB, were not ready for some challenges [21]. The activity of the NDB was somehow slowed down by political crisis in South Africa and Brazil, by the worsening of Chinese-Indian relations and the problems because of Western sanctions against some Russian companies. The BRICS countries were not sufficiently prepared to promote the interest of developing countries in the context of changing political context.

However, Brazil is still interested in fostering trade with other BRICS members. From 2006 to 2018 the Brazilian export to the BRICS countries grew 5 times [22], while China and South Africa managed to increase its export only 4 times, Russia - 3.4, and India 2.1 times [23]. 
It is worth mentioning Mr. Bolsonaro involved himself in a serious quarrel with West European leaders over a series of questions, mainly due to his views on environment protection and human rights. Mr. Emmanuel Macron from France and Ms. Angela Merkel from Germany rebuked Bolsonaro for his unwillingness to tackle the ongoing deforestation in Amazon. Months later it became public that Brazilian military have draft a document in which France was considered as the main source of external threat due to Macron's views on Amazon internationalization ${ }^{2}$. Russia and China are considered potential threats if they set up military bases in any point of South America [24].

\section{BRICS: is there a place for Argentina?}

From the first years of existence of BRICS group there were rumors and talks over possibilities to expand the group. Some countries (Turkey, Mexico, Saudi Arabia, Indonesia, Egypt, Argentine and Venezuela) expressed their willingness to increase cooperation with the BRICS and to think about possibilities of special status within this group. However, up to the moment the South Africa became the only new member of this alliance. At the Johannesburg Summit Russian President Vladimir Putin affirmed that the existing forms of the BRICS "are quite efficient" and, consequently, the time to "increase the number of the BRICS countries hasn't come yet" [25]. However, the Russian Minister for Foreign Affairs Sergei Lavrov, still made possible talks over the topic with his declaration that the BRICS is "working hard with a purpose to expand its frontiers and to form the external circle of fellows" [26].

During some last years the BRICS countries used the special format of "BRICS+" as a mode to expand the number of partners without their full admission into the group. Different countries were invited to the Summits with a purpose to coordinate policies in some crucial international issues and to negotiate over the problems significant for the BRICS members.

BRICS' VI summit in Brazilian Fortaleza was the first one for Argentina to take part in BRICS activities. This was especially important as Argentina was one of the "strategic partners" of Russia in South America and as it was called more than once as the possible new member of BRICS. Argentinean media was discussing enthusiastically the possibilities of joining this international club, and Jorge Capitanich, head of government of Cristina Fernandez de Kirschner's administration declared that "the BRICS and Argentina dispose the possibilities and perspective of growth, even in the scale of the whole planet" [27]. There were some plans for Putin's visit to Argentina in 2016 after the presidential elections in that South American nation, however, since the failure of the Kirschnerist candidate, Daniel Scioli, the visit was postponed and the talks over the possibility of Argentine's admission almost stopped.

However, the BRICS still was attractive for many local elites as the mode to improve Argentinean international prestige and to expand possibilities of getting loans and investment for some infrastructural projects [28]. The main objective reasons for Argentine possible joining the group was the fact that Buenos Aires has already built specific relations of close collaboration and cooperation with all the members of BRICS (and with China, Russia and Brazil it had even established "special strategic partnership") which might be-

\footnotetext{
${ }^{2}$ It must be cleared that Brazil does share borders with France, more specifically with French Guiana.
} 
come solid basis for future entry into the club. Another important feature, according to Argentinean media and ministers, was that Argentinean economy would "organically fit" into the whole economic structures of the BRICS, to supplement it and to contribute with agro-industrial resources. At the XXI ${ }^{\text {th }}$ century, Argentine became a global trader with more than 200 economic partners (while BRICS countries represent more than $38 \%$ of total volume of trade of this South American country: Brazil is the main trade partner, followed by China). It was also important that both Argentine and Brazil were founding members of South American common market (Mercosur) [29]. In 2018, during the G-20 summit in Buenos Aires, Argentinean government organized some meetings in formats of BRICS and RIC with a purpose to benefit from the presence of the leaders of this countries in South America. The membership of Argentine in G-20, together with all the BRICS countries, was also considered as an argument for further approximation between Buenos Aires and BRICS.

The consequent development of Argentinean economy and the growing number of problems within Argentinean economy made these arguments quite doubtful. However, the BRICS' dream, was very attractive for Buenos Aires, and the center-right government of Mauricio Macri (2015-2019) also had quite friendly attitude towards the BRICS, however, it was more interested in economic agenda of this group and was not ready to join efforts to change political international order. As Russian analyst Nailya Yakovleva has pointed, Macri even chose to go to the $10^{\text {th }}$ BRICS Summit in spite of visiting the Pacific Alliance Summit in Mexico City (although this Mexican summit was in full accordance with the Macri's economic policy). However, Brazilian objection to BRICS outreach format in 2019 at best postponed the discussions on the interaction between BRICS and Argentina.

Recently, the talks about Argentina's approximation with the BRICS groups began once again. According to Alicia Castro who has been designated as new Argentinean Ambassador to Russia, she would work hard to reach Argentina's integration into BRICS and she had already communicated it to the President Alberto Fernández [30]. The BRICS is perceived by both Fernández and Castro as "a strategic partner which is promoting the multi-polar world".

Right now, the idea about expansion of ties between Argentina and BRICS should be considered as part of the strategy of new Peronist government (to reestablish some regional integrationist groups as a counterbalance to the US influence and as pillars of multipolar world). However, the plans announced by Alicia Castro "there will be BRICS summit [in Russia] in July, and I aspire that Argentine would integrate into this block" seem rather premature. We definitely can't agree with Yakovleva's assumption [31] that there is a possibility for Argentina to become BRICS' member in near future despite all the volume of trade between BRICS countries and the South American nation, the cooperation in industrial and agrarian sectors as also in the investments area.

The agenda of BRICS' summit in July which would take place in Saint-Petersburg, doesn't include the topic of admission of new members. Even more important, there is no consensus about the necessity to increase number of affiliates. Last not least, some strong contradictions between current Argentinean and Brazilian governments make highly improbable the possibility to admit Argentina into the club. BRICS is not only, and not even mainly, political group (although its members very often demonstrate their autonomous line in international relations). However, the political divergences between candidates and 
current members of BRICS (or, at least, one of them) look as an obstacle impossible to overcome. Finally, the travel restrictions because of the COVID19 pandemic make impossible the realization of outreach format in Saint-Petersburg in 2020 and, consequently, all possible discussions of BRICS expansion became literally virtual.

\section{Brazil, Russia and BRICS: Some prospects}

The political character of relations between Moscow and Brasilia was demonstrated clearly during the Workers' Party government in 2014 when Brazil abstained to vote the draft of the UN resolution over the Ukraine's integrity (as all other BRICS members). While the political context has changed significantly especially since 2016, the basic features for maintaining good political relations still exist. The direct support for Brazil as a possible permanent UN Security Council member expressed by Moscow (while China only does it in indirect form) is quite important for Brasilia [32, p. 60]. However, the cooperation has its limits, and not only in political aspects. The volume of Russian-Brazilian trade is visibly less than Chinese-Brazilian trade. While the Brazilian media publish a lot of materials on collaboration with China, there is no comparable coverage by local newspapers and TV programs of significant events of Brazilian-Russian cooperation [33].

The future of Brazil-Russia relations remains still uncertain, dependent on political conjectures in Brazil. On the one hand, it is true that Bolsonaro's government embraced a more pragmatic attitude towards the world given the very meagre results obtained from the complete alignment with the US, paying a illustrative visit to Beijing in October 2019 to mend ties with its main importer and also relevant source of investments and later to New Deli to boost trade relations with India. On the other hand, however, Brasilia is still substantially loyal to Washington in many global disputes, hoping to obtain from the latter some political benefits, such as full support to accede the Organisation for Economic Cooperation and Development (OECD) and investments, even if it may hurt relations with Russia or even China.

The behavior of Brazilian successive administrations has varied over time since participating nations started to gather, since 2006. At least three distinct moments can be distinguished to date: (i) the enthusiastic years (2006-2011), when Brazilian representatives acted purposefully and hopefully to enhance intra-bloc interaction and to effectively change the balance of power in international institutions in favor of emerging nations; (ii) the disenchantment (2011-2016), a time when Brasilia showed less interest in changing current global order, but still looking for expanding intra-bloc (and even inter-regional) relations (iii) the distancing (from 2016), when Brazilian statemen started to demonstrate less confidence in BRICS as a group in favor of a bilateral approach.

During its early years, BRIC was seen in Brasilia as an opportunity to increase its international activism, by fostering dialogue and trade relations not only with other participants, but also to diversify its ties beyond the traditional bias towards the US and Western Europe. In that sense, BRIC was certainly not the unique grouping to address that demand from the then Brazilian administration. IBSA, an acronym encompassing India, Brazil and South Africa, was envisaged still in 2003, and seeks to increase the multisector interaction not only between its three members, but also to stimulate inter-regional synergies. It allowed for the signature of a preferential trade agreement (PTA) between Mercosur 
(Southern Common Market) and India in 2004. In 2008, another PTA was reached between Mercosur and Southern African Customs Union (SACU).

With the Global Economic Crisis in 2008-2009 offered additional incentives for BRIC, as the participating countries were not severely hit as the central developed markets in North America and West Europe. Brazilian administration sought together with other BRIC to press for some adjustments in international organizations in order to increase their own say. In conformity with Brasilia's will at that time, BRIC at that time manage to increase their voting power in the International Monetary Fund and the World Bank at the expense of traditional economic powers of North America and West Europe.

The second phase coincided roughly with Dilma Rousseff's presidencies (2011-2016) and was marked by a deterrent in Brazilian activism in international affairs, what also impacted in its acting within BRICS. The prevailing view in Brasilia consisted in expanding intra-bloc and inter-regional cooperation towards economic and political relations, but with less expectations in conceiving the group as a geopolitical tool to challenge or at least adjust global order. On the one hand, Brazil proposed in 2014 during its presidency of the bloc, the BRICS outreach, a formula that would be adopted in the following annual summits, in which the hosting nation invited its regional partners to follow the main discussions. In that year, the summit in Fortaleza for the first time brought together BRICS and UNASUR (Union of South American Nations ${ }^{3}$ ) members. The Brazilians cheered the creation of New Development Bank and BRICS Contingent Reserve Agreement, while also called for increasing trade and investment flows between its members.

On the other hand, Brasilia grew suspicious of developing the group as a geopolitical mechanism more focused on security issues, as desired by Beijing and particularly Moscow. The South Americans sustained that the group was too heterogeneous to form a unity in many global and regional questions, although they conceded that the group should discuss and promote peaceful resolution of conflicts and demand a more just and democratic global governance [34].

The removal of Rousseff in 2016 marked a radical change in Brazilian foreign policy. Its BRICS vector also underwent a major shift at that time. Brazilian diplomats became less inclined in the agenda of promoting the group as a whole. The new foreign policy showed less interest in discussing intra-bloc political concertation and even less in global governance forums, such as the United Nations Security Council. Even though the dialogue remained cordial with other BRICS members, Brazil started to emphasize bilateral relations instead of multilateral entanglements and discuss trade questions and avoid political and diplomatic commitments. In this context, Brasilia during the Michel Temer's administration paid more attention to the contacts with Beijing and New Delhi as those relations provided Brazil with the necessary basis for recovery of its economy [35]. The declarations made by Jose Serra (Brazilian Minister for Foreign Affairs in 2016) gave no room for political speculations: whole the foreign policy of Brazil had to be reformulated and exclude "political prerequisites" [36].

However, Brazil expressed more than once its willingness to be among founding members of both NDB and the Asian Investments Bank as it meant the demonstration of global strategic presence of the country. It is worth to note the "Freudian slip" made by Serra in November of 2016. While he was naming the BRICS members he didn't refer to the South

${ }^{3}$ UNASUR is a regional organization originally formed in 2008 by all 12 sovereign countries of South America. In 2018, Argentina, Brazil, Chile, Colombia and Ecuador suspended their membership. 
Africa, but mentioned Argentina as BRICS member [37]. Brasilia was and is decreasing its policy within the framework of "South-South cooperation" giving more importance to bilateral relations. China has more possibilities and resources for broadening its contacts with Brazil than Russia, however, Beijing would inevitably face the challenge of slowing down its own economy which would affect relations with South American countries. The decrease of Chinese demand for Brazilian resourced can't be substituted by other BRICS members; however, some improvement in Indian and Russian investments in Brazil might give new chance for bilateral relations. It was not accidentally, that during Temer's visit to Russia in 2017, both countries declared their willingness to enforce the strategic dialogue (including the BRICS, G20, the UN and other international formats) [38].

However, the election of Jair Bolsonaro as a President in late 2018 casted many uncertainties on nation's permanency in the group, given his strident anti-China discourses and the pervasive appraisal of the US during the electoral campaign. Even tough during initial months of his administration official Brazilians sought indeed to promote ostensibly the relations with Washington, the economic relevance of China as trade partner and source of investments in sensitive areas (particularly in ongoing privatization programs) pressed for the adoption of a more pragmatic stance on Beijing. At the meantime, as Getulio Vargas Foundation expert O. Stuenkel points out, the BRICS still maintains definite benefits for Brazil such as geopolitical significance (and possibility to play global role) [39], as also the door to increase the economic contacts with emerging Asian nations.

While it is always risky to anticipate scenarios, there are tiny chances of observing sudden changes in Brazilian engagement with BRICS for the next few years. Brasilia will continue participating the group, although its energy will remain underscored under Bolsonaro. A new era of activism could be plausible not only with a political shift in Brasilia, but also with the revival of national economy, which obtained very poor results during the 2010s.

\section{References}

1. BRICS and Latin America: positioning and interaction, ed. by Davydov, V., Moscow: ILA RAN Publ., 2010. (In Russian)

2. Foreign Policy Concept of the Russian Federation (approved by President of the Russian Federation Vladimir Putin on November 30, 2016). Available at: https://www.mid.ru/en/foreign_policy/official_documents/-/asset_publisher/CptICkB6BZ29/content/id/2542248 (accessed: 01.04.2020).

3. Concept of participation of the Russian Federation in BRICS. Available at: http://static.kremlin.ru/media/events/eng/files/41d452b13d9c2624d228.pdf (accessed: 01.04.2020).

4. Dobronravin, N. and Jeifets, V. (2019), Beyond the BRICS: Russian-Brazilian Relations since the collapse of the USSR, Pensamiento Propio, no. 49-50, pp. 199-228.

5. Cervo, A. (2008), Inserção Internacional: a formação dos conceitos brasileiros, São Paulo: Saraiva.

6. Bacigalupo, G.Z. (2000), As relações russo-brasileiras pós-Guerra Fria, Revista Brasileira de Política Internacional, no. 43 (2). Available at: http://www.scielo.br/pdf/rbpi/v43n2/v43n2a03.pdf (accessed: 21.02.2020).

7. Jubran, B. M. (2012), Brasile Rússia: política, comércio, ciência e tecnologia entre 1992 e 2010, Master Thesis, Porto Alegre, UFRGS. Available at: http://www.lume.ufrgs.br/bitstream/handle/10183/56075/000856969. pdf? sequence $=1$ (accessed: 21.02 .2020 ).

8. Cervo, A. L.and Lessa, A.C. (2014), The fall: the international insertion of Brazil (2011-2014), Revista Brasileira de Política Internacional, no. 57 (2), pp. 133-151. Available at: http://www.scielo.br/pdf/rbpi/ v57n2/0034-7329-rbpi-57-02-00133.pdf (accessed: 21.02.2020).

9. Saraiva, M. G. (2014), Balanço da política externa de Dilma Rousseff: perspectivas futuras?, Relações Internacionais, no. 44, pp. 25-35. Available at: http://www.scielo.mec.pt/scielo.php?script=sci_arttext\&pid $=$ S1645-91992014000400003 (accessed: 21.02.2020). 
10. Rosneft closed a deal to buy $100 \%$ of TNK-BP (2013), Forbes.ru, March 21. Available at: https:// www.forbes.ru/news/236055-rosneft-zakryla-sdelku-po-pokupke-100-tnk-vr (accessed: 01.04.2020). (In Russian)

11. Schreiber, M. (2017), Temer deixa G20 sem ter realizado nenhum encontro fechado com outro líder, BBC Brasil, July 8. Available at: http://www.bbc.com/portuguese/brasil-40545929 (accessed: 21.02.2020).

12. Spring, J. (2018), Discurso anti-China de Bolsonaro causa apreensão sobre negócios com o país, UOL, October 28. Available at: https://noticias.uol.com.br/politica/eleicoes/2018/noticias/reuters/2018/10/25/discurso-anti-china-de-bolsonaro-causa-apreensao-sobre-negocios-com-o-pais.htm (accessed: 21.02.2020).

13. Davedaño, T. (2018), Estados Unidos, um aliado acima de todos para o Brasil de Bolsonaro. El País Brasil, November 30. Available at: https://brasil.elpais.com/brasil/2018/11/29/internacional/1543517200_635889.html (accessed: 21.02.2020).

14. Bolsonaro reconhece Juan Guaidó como presidente da Venezuela (2019), Portal G1, January 23. Available at: https:/g1.globo.com/politica/noticia/2019/01/23/brasil-diz-que-reconhece-juan-guaido-como-presidente-da-venezuela.ghtml (accessed: 21.02.2020).

15. Serbin, A. (2019), La crisis venezolana llega a los BRICS, July 28. Available at https://www.perfil.com/ noticias/columnistas/la-crisis-venezolana-llega-a-los-brics.phtml (accessed: 21.02.2020).

16. Guaido supporters leave Venezuelan embassy in Brazil (2019), RIA Novosti, November 14. Available at: https://ria.ru/20191114/1560907721.html (accessed: 21.02.2020). (In Russian)

17. "Only peaceful, political, diplomatic settlement": Lavrov on the position of the BRICS countries in Venezuela, Russia Today. Available at: https://russian.rt.com/world/article/653489-lavrov-sovet-ministrovbriks (accessed: 21.02.2020). (In Russian)

18. Ministério das relações Exteriores (2019), XI Cúpula do BRICS - Declaração de Brasília, November 14. Available at: http://www.itamaraty.gov.br/pt-BR/notas-a-imprensa/21083-declaracao-de-brasilia11-cupula-do-brics (accessed: 21.02.2020).

19. Stuenkel, O. (2019), In Spite of Bolsonaro, China Quietly Deepens its Influence in Brazil, Americas quarterly, November 12. Available at: https://www.americasquarterly.org/content/spite-bolsonaro-chinaquietly-deepens-its-influence-brazil (accessed: 01.04.2020).

20. Cumbre de BRICS cierra sin grandes acuerdos y sin menciones a Venezuela y Bolivia (2019), Sputnik Mundo, November 14. Available at: https://mundo.sputniknews.com/politica/201911141089324892-cumbre-de-brics-cierra-sin-grandes-acuerdos-y-sin-menciones-a-venezuela-y-bolivia/ (accessed: 01.04.2020).

21. Andreoni, M., What happened to the BRICS bank?, The Third Pole. Available at: https://www.thethirdpole.net/en/2019/11/18/what-happened-to-the-brics-bank/ (accessed: 01.04.2020).

22. Jeifets, V., Khadorich, L. and Leksyutina, Y.(2018), Russia and Latin America: Renewal versus Continuity, Portuguese Journal of Social Science, vol. 17, no. 2, pp. 213-228.

23. Yakovlev, P.(2019), BRICS Summit focuses on innovation, Nezavisimaia gazeta, November 10. Available at: http://www.ng.ru/dipkurer/2019-11-10/9_7722_brasil.html?print=Y (accessed: 03.04.2020). (In Russian)

24. Gielow, I. (2020), Elite militar brasileira vê França como ameaça nos próximos 20 anos, Folha de São Paulo, February 7. Available at: https://www1.folha.uol.com.br/mundo/2020/02/elite-militar-brasileira-vefranca-como-ameaca-nos-proximos-20-anos.shtml (accessed: 21.02.2020).

25. Putin: BRICS does not plan to include new countries (2018), TASS, July 27. Available at: https://tass. ru/politika/5409102 (accessed: 06.01.2019). (In Russian)

26. Lavrov: BRICS countries intend to actively form an external circle of like-minded people (2018), TASS, 25.07. Available at: https://tass.ru/politika/5400860 (accessed: 16.01.2019). (In Russian)

27. Tras invitación de Rusia al Brics, Gobierno no descarta visita de Putin. Available at: http://www.ambito.com/noticia.asp?id=743028 (accessed: 06.12.2018).

28. La Argentina sueña con los Brics, pero la puerta sigue cerrada. Available at: https://www.lanacion. com.ar/1709467-la-argentina-suena-con-los-brics-pero-la-puerta-siguecerrada (accessed: 06.11.2019).

29. Mauricio Macri: «Mejorarán las relaciones históricas entre Argentina y Brasil». Available at: https:// www.infobae.com/politica/2019/01/16/macri-considero-exitosa-su-visita-abrasil-y-apuesta-a-una-relacion-estrategica-con-bolsonaro/1 (accessed: 18.03.2020).

30. Longy, A., Alicia Castro y sus planes como embajadora en Rusia: “Trabajaré para que Argentina se integre a los Brics", Entrevista en AM750. Available at: https://www.pagina12.com.ar/246918-alicia-castroy-sus-planes-como-embajadora-en-rusia-trabajar?fbclid=IwAR3O4e4_VduC0wCDP73z1lL0XQiWaPsCkM0L8aeIXkYNZBpukdCy3-ycClU (accessed: 01.04.2020).

31. Yakovleva, N.M.(2019), BRICS countries and Argentina: potential of the interaction. Towards the summit in Brazil, Latinskaia Amerika, no. 4, pp. 5-19. (In Russian) 
32. Ellis, R.E. (2015), The New Russian Engagement with Latin America: Strategic Position, Commerce, and Dreams of the Past, Army War College Carlisle Barracks PA Strategic Studies Institute.

33. Ehrmann, E. (2016), Russia and Brazil - What Will Come After Rousseff?, April 14. Available at: http://russiancouncil.ru/inner/?id_4=7542\#top-content (accessed: 18.11.2017).

34. Becard, D. R., Barros-Platiau, A.F. and Oliveira, C.C.de (2015), O Brasil, a China e a VI Cúpula do BRICS, Contexto Internacional, vol. 37 (1), pp. 81-112. DOI: https://doi.org/10.1590/S010285292015000100003.

35. Stuenkel, O. (2016), BRICS ainda é prioridade estratégica para o Brasil, El País, June 30.

36. Stuenkel, O. (2016), Brazil: Towards a New Foreign Policy?, Post-Western World, May 20. Available at: http://www.postwesternworld.com/2016/05/20/brazil-towards-foreign/ (accessed: 18.11.2017).

37. Vieira, M. and Menezes, H. (2016), Brazil is breaking with its south-south focus. What it means for BRICS, The Conversation, November 20. Available at: https://theconversation.com/brazil-is-breaking-withits-south-south-focus-what-it-means-for-brics-69008 (accessed: 18.11.2017).

38. Joint statement by the Russian Federation and the Federal Republic of Brazil on strategic foreign policy dialogue (2017), June 21. Available at: http://www.kremlin.ru/supplement/5212 (accessed: 01.04.2020).

39. Oliver Stuenkel Para lidar com a China, Bolsonaro tem um instrumento nas mãos (2019), El Pais (Brasil), January 21.

Received: April 10, 2020

Accepted: June 15, 2020

Authors' information:

Victor Jeifets - Dr. Sci. in History, Professor; jeifets@gmail.com

Bruno Mariotto Jubran — PhD of International Strategic Studies; mariotto.bruno@gmail.com 